\title{
Modulation of photosynthesis, nitrogen fixing ability, and yield attributes of Chickpea (Cicer arietinum L.) to interactive effect NPK fertilizers and municipal wastewater irrigation
}

\author{
Hamid Iqbal Tak ${ }^{1,2 *}$ \\ 'Department of Botany, Aligarh Muslim University, Aligarh, India. \\ ${ }^{2}$ Department of Applied Biotechnology, University of Technology and Applied Sciences, Sultanate of Oman.
}

\section{ARTICLE INFO}

Article history:

Received on: December 26, 2020

Accepted on: February 16, 2021

Available online: May 10, 2021

\section{Key words:}

Municipal wastewater,

NPK fertilizers,

Photosynthetic rate,

Nodulation,

Protein content,

Yield.

\begin{abstract}
In recent years, the urban wastewater of marginal quality is increasingly being used to irrigate lands for growing crops. However, water reuse in agriculture needs specific studies to evaluate its safe use depending upon the choice of the crop and soil type. A pot experiment was therefore, conducted to investigate the effect of different fertilizer combinations, that is, nitrogen, phosphorus and potassium (NPK) on chickpea (Cicer arietinum L.) irrigated with sewage wastewater (WW), and ground water (GW). The objective of this experiment was to evaluate optimal fertilizer requirement based on growth, physiological determinants, and the yield of chickpea under wastewater irrigation. Results revealed the positive influence of wastewater and optimal growth and yield of the crop were obtained with a relatively lower fertilizer combination of $\mathrm{N}_{30} \mathrm{P}_{60} \mathrm{~K}_{40}$ when irrigated with wastewater. Physiological parameters of plants being irrigated with wastewater were also enhanced when compared to ground water irrigated plants and it was expressed by significant improvement in the yield parameters of the crop. The nutrients present in wastewater therefore proved beneficial for the crop yield and also reduced the nutritional requirement of the crop to be supplied in the form of fertilizers. It can therefore serve not only as an alternative disposal of wastewater but even supplement the nutritional requirement of the crop. However, its long-term usage needs to be closely monitored for any heavy metal buildup in soil as their presence in wastewater could be a cause of concern.
\end{abstract}

\section{INTRODUCTION}

Water is a vital natural resource but often limited in most of the countries including India. Consumptive use of water in agriculture is highest and greater water availability is associated with improved agricultural performance and hence food security [1]. In recent years, the demand of water has increased at a much faster rate due to increase in the human population, industrialization, and agricultural its related activities. Furthermore, the water resources are shrinking rapidly and the continuous discharge of the wastewater in the water bodies is polluting the aquatic ecosystem [2]. Thus, we not only need to save but also utilize water optimally. Only then we will be able to solve the environmental crisis which can arise out of acute water shortages. In different parts of the world widespread shortage of water has forced us to think of new alternatives for supplying water for the growing crops. The significance of water in sustaining the livelihood is well known and therefore to conserve and optimally utilize the water in agriculture is of prime importance which is already facing shortage of quality

\section{*Corresponding Author:}

Hamid Iqbal Tak,

Department of Applied Biotechnology, University of

Technology and Applied Sciences, Sultanate of Oman. Department of Botany,

Aligarh Muslim University, Aligarh, India.E-mail: hamid.iqbal2007@gmail.com water. Agriculture stands to be the single largest user of water and in past few decades the water reuse is being suggested as one solution to inadequate water supplies [3]. Reuse of treated sewage wastewater can reduce effluent discharges into fresh waters and can not only solve the problem of disposal but supplement the nutritional needs of the crops. Its reuse therefore has a potential to offer a more reliable water supply for agricultural practices. It therefore can reduce the burden from the limited potable water resources. In recent years, several reports have been published where wastewater has been described to contribute in increasing yields along with numerous other benefits and offers (i) environmental friendly method of wastewater disposal leading to recycling of nutrients [4], (ii) reduction in the cost of fertilizers by supplementing nutrients present in wastewater [5], and (iii) reduction in the demand of fresh water in agriculture which can be made available to the ever increasing population for fresh water needs [6].

However, there is a wide spread concern about its adverse effect and health hazards to the consumers using the crops grown on wastewater $[7,8]$. It is also widely accepted that proper handling and management are of vital importance for safe use of wastewater in agriculture. Therefore, if it is used systematically and monitored periodically, it may be considered a sound and environmental reliable mode of wastewater disposal [9] and also depends upon the type of soil [10]. 
Wastewater reuse is advantageous for many reasons. Wastewater contains essential macro and micro nutrients and more notably a significant amount of organic matter, thereby making it a rich source of nutrients. As there are strict discharge requirements and shortages in the nutrient supply [11], these nutrients can be utilized to increase the growth and productivity of agricultural crops helping in social sustainability [12,13]. However, improper management of water and their continuous use to the crops can provide nutrients beyond their specific requirement. Over the period of years these may get accumulated to an undesirable levels resulting in their accumulation [14] and even soil salinization and reduction in permeability $[15,16]$.

The use of marginal quality wastewater has a potential to address the problem of water shortage in agriculture; however, fewer studies are available on its long-term effects. Sufficient scope, therefore, exists for conservative and sustainable use of water in agriculture and improvement in its equitable distribution among users by adopting a variety of measures such as (i) selection of varieties and crops for higher water use efficiency, (ii) adopting soil water management, (iii) need based irrigation, and (iv) use of treated wastewater or sewage water.

This study mainly focusses on the last point. Compared with other types of water reuse, applying wastewater to agriculture presents an additional benefit of nutrient recycling in crop irrigation. There have been numerous studies showing successful usage of recycled agricultural wastewater over the past few decades on horticultural crops [17-19] and grasslands [20]. However, very few studies have been conducted on its effect on nitrogen fixing crops. This study was therefore undertaken to study the application of wastewater along with different levels of NPK on growth, physiology, and yield of Cicer arietinum L. (Chickpea). The choice of the crop was made in view of its low water requirement and nitrogen fixing ability. This experiment is the final part of the earlier three experiments conducted separately for optimal doses of nitrogen, phosphorus, and potassium published elsewhere $[4,9,21]$.

\section{MATERIALS AND METHODS}

\subsection{Design of Experiment}

The wastewater was collected in big containers from the site nearly $10 \mathrm{~km}$ from the town and about $15 \mathrm{~km}$ away from the site of experiment. The waste water is being used by local farmers to irrigate their fields to grow various crops; however, the present experiment was conducted in the net house of the department of Botany Aligarh Muslim University, Aligarh. Each treatment was set simultaneously in triplicate using a completely randomized block design, with eight combinations of nitrogen $(\mathrm{N})$, phosphorus $(\mathrm{P})$, and potassium $(\mathrm{K})$, that is, NPK treatments $\mathrm{N}_{0} \mathrm{P}_{0} \mathrm{~K}_{0}, \mathrm{~N}_{15} \mathrm{P}_{40} \mathrm{~K}_{20}, \mathrm{~N}_{15} \mathrm{P}_{40} \mathrm{~K}_{40}, \mathrm{~N}_{15} \mathrm{P}_{60} \mathrm{~K}_{20}, \mathrm{~N}_{15} \mathrm{P}_{60} \mathrm{~K}_{40}$, $\mathrm{N}_{30} \mathrm{P}_{40} \mathrm{~K}_{20}, \mathrm{~N}_{30} \mathrm{P}_{40} \mathrm{~K}_{40}, \mathrm{~N}_{30} \mathrm{P}_{60} \mathrm{~K}_{20}$, and $\mathrm{N}_{30} \mathrm{P}_{60} \mathrm{~K}_{40}$ [Table 1]. The outline of the experiment representing the NPK treatments and wastewater is shown in Table 1. Each set of plants was irrigated by ground water $(\mathrm{GW})$ and urban wastewater (WW) collected from drain from time to time. The seeds of Cicer arietinum L. were surface sterilized with $0.5 \%(\mathrm{v} / \mathrm{v})$ of sodium hypochlorite solution. The sterilized seeds were then washed repeatedly with double distilled water (DDW) and then inoculated with Rhizobium spp. The seeds after inoculation were sown in earthen pots (10 inch diameter).

\subsection{Water and Wastewater}

The physico-chemical properties of ground water (GW) and urban wastewater $(\mathrm{WW})$ were recorded at the start and toward the end of the experiment and the mean values were recorded [Table 2]. The frequency of watering the plants was maintained as per the requirement of the crops and it was distributed equally among the plants. The fresh water samples were collected and analyzed for physico-chemical characteristics immediately after collection [Table 2], adopting the procedures as outlined in the standard method [22]. Heavy metals such as cadmium, chromium, lead, and nickel in both the waters were also analyzed using the atomic absorption spectrophotometer. The microbiological analysis was carried out from three freshly collected water samples and mean values were recorded [Table 2].

Table 1: Experimental design.

\begin{tabular}{lccc} 
NPK $(\mathbf{k g} / \mathbf{h a})$ & \multicolumn{2}{c}{ Irrigation water } & \multicolumn{1}{c}{ Remarks } \\
\cline { 2 - 3 } & GW & WW & \\
$\mathrm{N}^{0} \mathrm{P}^{0} \mathrm{~K}^{0}$ & + & + & No fertilizer \\
$\mathrm{N}^{15} \mathrm{P}^{40} \mathrm{~K}^{20}$ & ++ & ++ & 15,40 , and $20 \mathrm{~kg} \mathrm{NPK} / \mathrm{ha}$ \\
$\mathrm{N}^{15} \mathrm{P}^{40} \mathrm{~K}^{40}$ & ++ & ++ & 15,40 , and $40 \mathrm{~kg} \mathrm{NPK} / \mathrm{ha}$ \\
$\mathrm{N}^{15} \mathrm{P}^{60} \mathrm{~K}^{20}$ & ++ & ++ & 15,60 , and $20 \mathrm{~kg} \mathrm{NPK} / \mathrm{ha}$ \\
$\mathrm{N}^{15} \mathrm{P}^{60} \mathrm{~K}^{40}$ & ++ & ++ & 15,60 , and $40 \mathrm{~kg} \mathrm{NPK} / \mathrm{ha}$ \\
$\mathrm{N}^{30} \mathrm{P}^{40} \mathrm{~K}^{20}$ & ++ & ++ & 30,40 , and $20 \mathrm{~kg} \mathrm{NPK} / \mathrm{ha}$ \\
$\mathrm{N}^{30} \mathrm{P}^{40} \mathrm{~K}^{40}$ & ++ & ++ & 30,40 , and $20 \mathrm{~kg} \mathrm{NPK} / \mathrm{ha}$ \\
$\mathrm{N}^{30} \mathrm{P}^{60} \mathrm{~K}^{20}$ & ++ & ++ & 30,60 , and $20 \mathrm{~kg} \mathrm{NPK} / \mathrm{ha}$ \\
$\mathrm{N}^{30} \mathrm{P}^{60} \mathrm{~K}^{40}$ & ++ & ++ & 30,60 , and $40 \mathrm{~kg} \mathrm{NPK} / \mathrm{ha}$ \\
\hline
\end{tabular}

The NPK doses for pots were calculated on the basis of their composition and that one hectare of land contains $2 \times 10^{6} \mathrm{~kg}$ effective soil

Table 2: Physico-chemical and microbiological parameters of water and wastewater given in $\mathrm{mg} / \mathrm{L}$ or as specified.

\begin{tabular}{|c|c|c|c|}
\hline Parameter & $\begin{array}{c}\text { Ground } \\
\text { water }(\mathbf{G W})\end{array}$ & $\begin{array}{c}\text { Wastewater } \\
\text { (WW) }\end{array}$ & $\begin{array}{l}\text { FAO irrigation } \\
\text { water quality* }\end{array}$ \\
\hline $\mathrm{pH}$ & 7.3 & 7.7 & $6.5-8.4$ \\
\hline $\mathrm{EC}\left(\mu\right.$ mhos $\left.\mathrm{cm}^{-1}\right)$ & 645 & 1495 & $0.25-3$ \\
\hline TS & 1020 & 1990 & - \\
\hline TDS & 630 & 1424 & $<2000$ \\
\hline TSS & 390 & 576 & - \\
\hline $\mathrm{NO}_{3}-\mathrm{N}$ & 0.83 & 3.65 & $<10$ \\
\hline $\mathrm{NH}_{4}-\mathrm{N}$ & 0.18 & 4.84 & $<5$ \\
\hline $\mathrm{PO}_{4}^{-3}$ & 0.42 & 1.59 & $<2$ \\
\hline $\mathrm{K}^{+}$ & 3.42 & 18.44 & $<2$ \\
\hline $\mathrm{Ca}^{2+}$ & 22.45 & 62.12 & $<400$ \\
\hline $\mathrm{Mg}^{2+}$ & 32.41 & 142.44 & $<61$ \\
\hline $\mathrm{Cl}^{-}$ & 48.75 & 127.62 & $<350$ \\
\hline $\mathrm{CO}_{3}^{-2}$ & 54.28 & 114.85 & - \\
\hline $\mathrm{HCO}_{3}^{-}$ & 99.85 & 84.29 & $<610$ \\
\hline $\mathrm{SO}_{4}$ & 34.58 & 92.56 & - \\
\hline $\mathrm{Na}^{+}$ & 22.45 & 62.48 & $<460$ \\
\hline $\mathrm{Cd}$ & ND & 0.008 & - \\
\hline $\mathrm{Cr}$ & ND & 0.006 & - \\
\hline $\mathrm{Ni}$ & ND & 0.498 & - \\
\hline $\mathrm{Pb}$ & ND & 0.039 & - \\
\hline Coliforms (MPN) & ND & $\begin{array}{c}2.3 \times 10^{3} \\
\text { CFU } 100 / \mathrm{ml}\end{array}$ & - \\
\hline $\begin{array}{l}\text { Fecal coliforms } \\
\text { (MPN) }\end{array}$ & ND & $\begin{array}{c}9.9 \times 10^{2} \\
\text { CFU } 100 / \mathrm{ml}\end{array}$ & - \\
\hline
\end{tabular}

*Ayers and Wescot 1994. (-) means no standard mentioned 


\subsection{Soil Analysis}

The soil was collected from the fields and thoroughly mixed with farmyard manure. The soil samples were collected before starting the experiment and mean values were recorded. These soil samples were also analyzed for standard physico-chemical properties [Table 3] [23,24].

\subsection{Plant Analysis}

The plants were analyzed at various stages of growth and the first sampling was done at 60 days after sowing (DAS) which is being reported in the current experiment. After the plants were gently uprooted, they were first washed to clean the adhering soil and then wrapped in the tissue paper to absorb excess water. The length of plant and its fresh mass was recorded. The samples were then dried in an oven, run at $80^{\circ} \mathrm{C}$ for $48 \mathrm{~h}$ and then these dried samples were weighed on a digital balance.

Furthermore, from the additional set of plants from each treatment, the root nodules were also separated. After recording the fresh mass, the dry mass was recorded after dehydrating them in the oven for $48 \mathrm{~h}$. The fresh nodules collected from the additional sets were then mixed with $3 \mathrm{ml}$ of $0.1 \mathrm{M}$ sodium phosphate buffer and macerated in a mixture. It was soon filtered through two layers of cheese cloth. It was the centrifuged at 10,000 rpm for 10-30 min. Three milliliters of this extract were mixed with $3 \mathrm{ml}$ of pyridine reagent and thoroughly mixed. The solution due to formation of hemochrome turns greenishyellow. The hemochrome was then divided equally in two test tubes. To one test tube, a few crystals of hexacyanoferrate were added to oxidize the hemochrome. It was read at $539 \mathrm{~nm}$ on spectrophotometer. To the other test tube, a few crystals of sodium dithionite were added to reduce the hemochrome. This mixture was read at $556 \mathrm{~nm}$ after an interval of 2-5 min, against a reagent blank and leghemoglobin content was calculated [25].

The NR activity was also estimated by the intact tissue method [26], while carbonic anhydrase (CA) activity was determined in fresh leaves of plants by the method of Dwivedi and Randhawa [27]. Leaf area was measured using a portable leaf area meter (LA-21, Systronics, India).

Table 3: Physical and chemical parameters of soil. All determinations in $\mathrm{mg} / \mathrm{L}$ in 1:5 (soil-water) extract or as specified.

\begin{tabular}{lc}
\multicolumn{1}{c}{ Determinations } & Value \\
Soil texture & Sandy Loam \\
$\mathrm{CEC}($ meq $100 / \mathrm{g}$ soil) & 2.08 \\
$\mathrm{pH}$ & 7.92 \\
Organic carbon (\%) & 0.639 \\
$\mathrm{EC}(\mu \mathrm{mhos} / \mathrm{cm})$ & 306.00 \\
$\mathrm{NO}_{3}^{-}-\mathrm{N}(\mathrm{g} / \mathrm{kg}$ soil) & 0.330 \\
Phosphorus $(\mathrm{g} / \mathrm{kg}$ soil) & 0.104 \\
Potassium & 8.2 \\
Calcium & 33.42 \\
Magnesium & 16.85 \\
Chloride & 31.11 \\
Carbonate & 32.73 \\
Bicarbonate & 115.32 \\
Sodium & 14.73 \\
Sulfate & 17.27 \\
\hline
\end{tabular}

The photosynthetic parameters including the net photosynthetic rate $\left(\mathrm{P}_{\mathrm{N}}\right)$ and stomatal conductance $\left(\mathrm{g}_{\mathrm{s}}\right)$ at sampling were measured in fully expanded leaves from the upper portion of the plant on clear sunny days between 1100 and $1230 \mathrm{~h}$, using portable photosynthetic system (LICOR 6400, Lincoln, NE, USA). Leaf nitrogen was estimated by the method of Lindner [28], while the method of Mackinney [29] was used to calculate the total chlorophyll content. At harvest, yield attributes including seeds per pod, pods per plant, 100 seed weight, seed yield per plant were noted and protein content in the seeds was measured by the method of Lowry [30].

\subsection{Data Analysis}

The experimental data were statistically analyzed using two-way analysis (ANNOVA) in the SPSS software package. The means were compared using the least significant difference [31]. Correlation coefficient (r) values of $\mathrm{N}$ content and protein content; leaf area; and net photosynthetic rates were also worked out and graphs were plotted using excel.

\section{RESULTS AND DISCUSSION}

The characteristics of water presented in Table 1 showed that $\mathrm{pH}$ of both the ground water and wastewater ranged from 7.3 to 7.7 , respectively. Only potassium $(\mathrm{K})$ and magnesium $(\mathrm{Mg})$ in wastewater were reported above the limit, while the important parameters including the electrical conductivity (EC), TDS, $\mathrm{Na}^{+}, \mathrm{Cl}^{-}$, and other observed parameters were recorded within the permissible limits as prescribed by FAO guidelines for irrigation waters [32]. Among the heavy metals, only cadmium $(\mathrm{Cd})$, chromium $(\mathrm{Cr})$, nickel $(\mathrm{Ni})$, and lead $(\mathrm{Pb})$ were analyzed and were found to be well within the permissible limits. The microbes such as coliforms $\left(2.3 \times 10^{3} \mathrm{CFU} 100^{-1}\right)$ and fecal coliforms $\left(9.9 \times 10^{2} \mathrm{CFU}\right.$ $100 \mathrm{ml}^{-1}$ ) were present in wastewater and were not detected in ground water. This may be a cause of concern particularly if this water is used for vegetable crops and if the crop is eaten raw.

\subsection{Growth Parameters}

The data presented in Table 4 showed significant variations in the shoot length, root length, plant fresh mass, and plant dry mass among the plants irrigated with ground water and wastewater. Improved morphological characteristics were observed in the wastewater irrigated plants. Moreover, the dry matter in plants which were irrigated using wastewater recorded an increase of $15.92 \%$ over the ground water irrigated plants. Among the treatments also significant differences in the growth characteristics were observed. Mostly among the growth parameters, the treatment $\mathrm{N}_{30} \mathrm{P}_{40} \mathrm{~K}_{40}$ proved better and an increase of $48.50 \%$ in shoot length, 46.83 in root length, $31.91 \%$ in plant fresh mass, and $32.8 \%$ in plant dry matter over the control was noted. However, among the interactions the lower fertilizer dose of $\mathrm{N}_{15} \mathrm{P}_{60} \mathrm{~K}_{40}$ along with wastewater proved better and recorded an increase of $59.67 \%$ over the control. It is well documented that the wastewater alone cannot meet the nutritional requirement of the crop [33] and the positive of role of wastewater to lower the chemical fertilizers requirement has been reported earlier by Singh et al. [34], Mojid et al. [35].

\subsection{Nodulation}

The nodule number, nodule fresh mass, dry mass, and leghemoglobin content were significantly affected under the influence wastewater and also under different fertilizations [Table 5]. The higher nodule number, fresh mass, and dry mass may be due to better fertilization, which in turn enhanced the nitrogen fixing ability of the plant which can be 
Table 4: Effect of GW and WW on plant (a) shoot length, (b) root length, (c) plant fresh mass, and (d) dry mass of chickpea (Cicer arietinum L.) grown under different combinations of NPK at 60 DAS.

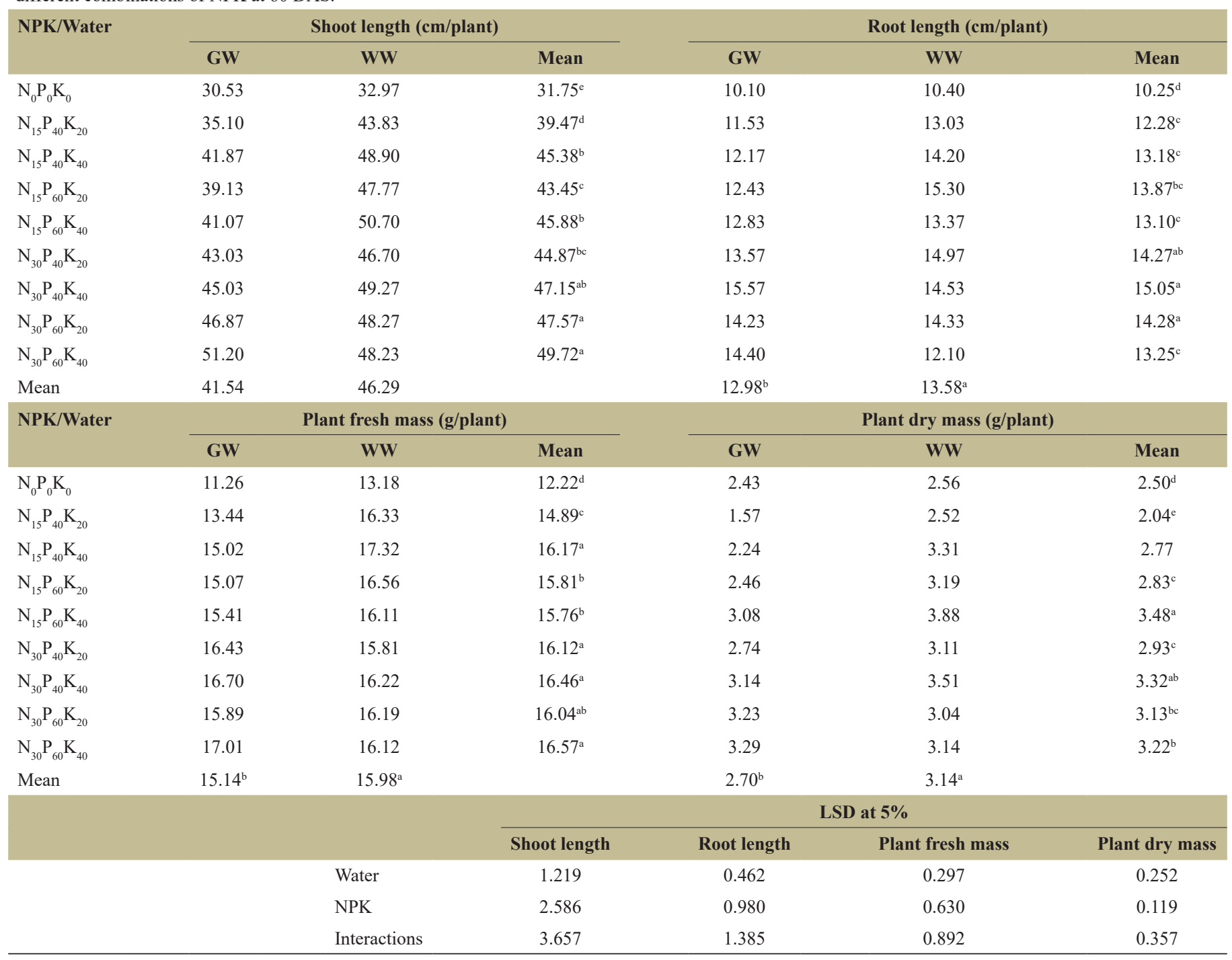

Table 5: Effect of GW and WW on plant (a) nodule number, (b) nodule fresh mass, (c) nodule dry mass and (d) leghaemoglobin content of chickpea (Cicer arietinum L.) grown under different combinations of NPK at 60 DAS.

\begin{tabular}{|c|c|c|c|c|c|c|}
\hline \multirow[t]{2}{*}{ NPK/Water } & \multicolumn{3}{|c|}{ Nodule number } & \multicolumn{3}{|c|}{ Nodule fresh mass (mg/plant) } \\
\hline & GW & WW & Mean & GW & WW & Mean \\
\hline $\mathrm{N}_{0} \mathrm{P}_{0} \mathrm{~K}_{0}$ & 28.67 & 35.33 & $32.00^{\mathrm{c}}$ & 302.03 & 328.53 & $315.28^{\mathrm{e}}$ \\
\hline $\mathrm{N}_{15} \mathrm{P}_{40} \mathrm{~K}_{40}$ & 35.33 & 47.67 & $41.50^{\mathrm{ab}}$ & 362.40 & 397.60 & $380.00^{c}$ \\
\hline $\mathrm{N}_{15} \mathrm{P}_{60} \mathrm{~K}_{20}$ & 32.33 & 51.67 & $42.00^{\mathrm{a}}$ & 348.43 & 395.43 & $371.93^{\mathrm{c}}$ \\
\hline $\mathrm{N}_{15} \mathrm{P}_{60} \mathrm{~K}_{40}$ & 42.33 & 48.33 & $45.33^{\mathrm{a}}$ & 384.40 & 402.63 & $393.52^{\mathrm{b}}$ \\
\hline $\mathrm{N}_{30} \mathrm{P}_{40} \mathrm{~K}_{40}$ & 47.33 & 39.67 & $43.50^{\mathrm{a}}$ & 402.10 & 412.53 & $407.32^{\mathrm{a}}$ \\
\hline $\mathrm{N}_{30} \mathrm{P}_{60} \mathrm{~K}_{20}$ & 42.33 & 45.33 & $43.83^{\mathrm{a}}$ & 386.47 & 407.60 & $397.03^{\mathrm{ab}}$ \\
\hline $\mathrm{N}_{30} \mathrm{P}_{60} \mathrm{~K}_{40}$ & 49.67 & 41.33 & $45.50^{\mathrm{a}}$ & 409.10 & 399.60 & $404.35^{\mathrm{a}}$ \\
\hline Mean & $39.04^{\mathrm{b}}$ & $44.44^{\mathrm{a}}$ & & $369.77^{\mathrm{b}}$ & $390.54^{a}$ & \\
\hline
\end{tabular}


Table 5: (Continued)

\begin{tabular}{|c|c|c|c|c|c|c|}
\hline \multirow[t]{2}{*}{ NPK/Water } & \multicolumn{3}{|c|}{ Nodule dry mass (mg/plant) } & \multicolumn{3}{|c|}{ Leghemoglobin content [mmol (g/FM)] } \\
\hline & GW & WW & Mean & GW & WW & Mean \\
\hline $\mathrm{N}_{0} \mathrm{P}_{0} \mathrm{~K}_{0}$ & 82.11 & 85.91 & $84.01^{\mathrm{g}}$ & 44.66 & 49.29 & $46.98^{\mathrm{e}}$ \\
\hline $\mathrm{N}_{15} \mathrm{P}_{40} \mathrm{~K}_{40}$ & 91.42 & 115.85 & $103.64^{\mathrm{e}}$ & 58.50 & 66.98 & $62.74^{\mathrm{bc}}$ \\
\hline $\mathrm{N}_{15} \mathrm{P}_{60} \mathrm{~K}_{20}$ & 95.14 & 112.12 & $103.63^{\mathrm{e}}$ & 57.26 & 67.60 & $62.43^{\mathrm{c}}$ \\
\hline $\mathrm{N}_{30} \mathrm{P}_{40} \mathrm{~K}_{40}$ & 109.93 & 114.42 & $112.18^{\mathrm{b}}$ & 65.90 & 61.51 & $63.71^{\mathrm{b}}$ \\
\hline $\mathrm{N}_{30} \mathrm{P}_{60} \mathrm{~K}_{20}$ & 107.89 & 110.66 & $109.27^{\mathrm{c}}$ & 64.97 & 62.53 & $63.75^{\mathrm{b}}$ \\
\hline $\mathrm{N}_{30} \mathrm{P}_{60} \mathrm{~K}_{40}$ & 117.49 & 112.06 & $114.77^{\mathrm{a}}$ & 67.96 & 63.65 & $65.81^{\mathrm{a}}$ \\
\hline \multirow[t]{2}{*}{ Mean } & $99.94^{\mathrm{b}}$ & $107.93^{\mathrm{a}}$ & & $59.51^{\mathrm{b}}$ & $61.95^{\mathrm{a}}$ & \\
\hline & & Interaction & 6.75 & 16.93 & 3.14 & 1.69 \\
\hline
\end{tabular}

ascribed to the fact that plants receiving wastewater as the irrigation water reported improved leghemoglobin content. Significant role of wastewater in improving the nitrogen fixation has also been reported in Vicia faba [36]. However, certain groups of microbes, particularly the asymbiotic and heterotrophic bacteria have been reported to be sensitive to long-term contamination by wastewater [37].

\subsection{Physiological Parameters}

The elementary physiological parameters including leaf area, chlorophyll content was more in plants receiving wastewater as irrigation water and thereby positively affected the net photosynthetic rate. All these photosynthetic parameters were significantly affected by the application of different waters and also under different fertilizer combinations. The plants receiving wastewater reported an increase of $7.80 \%$ in leaf area, $4.61 \%$, in chlorophyll content, and $6.14 \%$ in photosynthetic rate [Table 6]. Among the fertilizer treatments $\mathrm{N}_{30} \mathrm{P}_{40} \mathrm{~K}_{40}$ was reported as the optimum combination and an increase of $29.04 \%, 37.81 \%, 23.78 \%$, and $15.00 \%$ in leaf area, nitrate reductase, chlorophyll content, and carbonic anhydrase was recorded over the control $\mathrm{N}_{0} \mathrm{P}_{0} \mathrm{~K}_{0}$, respectively. Nitrate reductase activity also improved considerable in wastewater irrigated plants and an increase of $7.29 \%$ was reported over plants irrigated with ground water. The nitrate reductase enzyme in plants uses nitrates and reduces it to nitrites which are then transformed to ammonia for subsequent incorporation into various compounds.

The enzyme carbonic anhydrase (CA) responsible for the reversible hydration of $\mathrm{CO}_{2}$ and is necessary for optimal photosynthetic activity [38]. Its activity has been reported to decline within few days if nitrogen is deficient [39] as may be observed under lower nitrogen dose [Table 6]. This is further strengthened by an increase in CA activity by $16.78 \%$ over control in plants treated with $\mathrm{N}_{30} \mathrm{P}_{60} \mathrm{~K}_{40}$ [Table 6].

The net photosynthetic rate gives an indication of photosynthetic activity in plants and is functionally dependent upon the chlorophyll content. Similarly, the photosynthetic parameters including net photosynthetic rate and stomatal conductance and water use

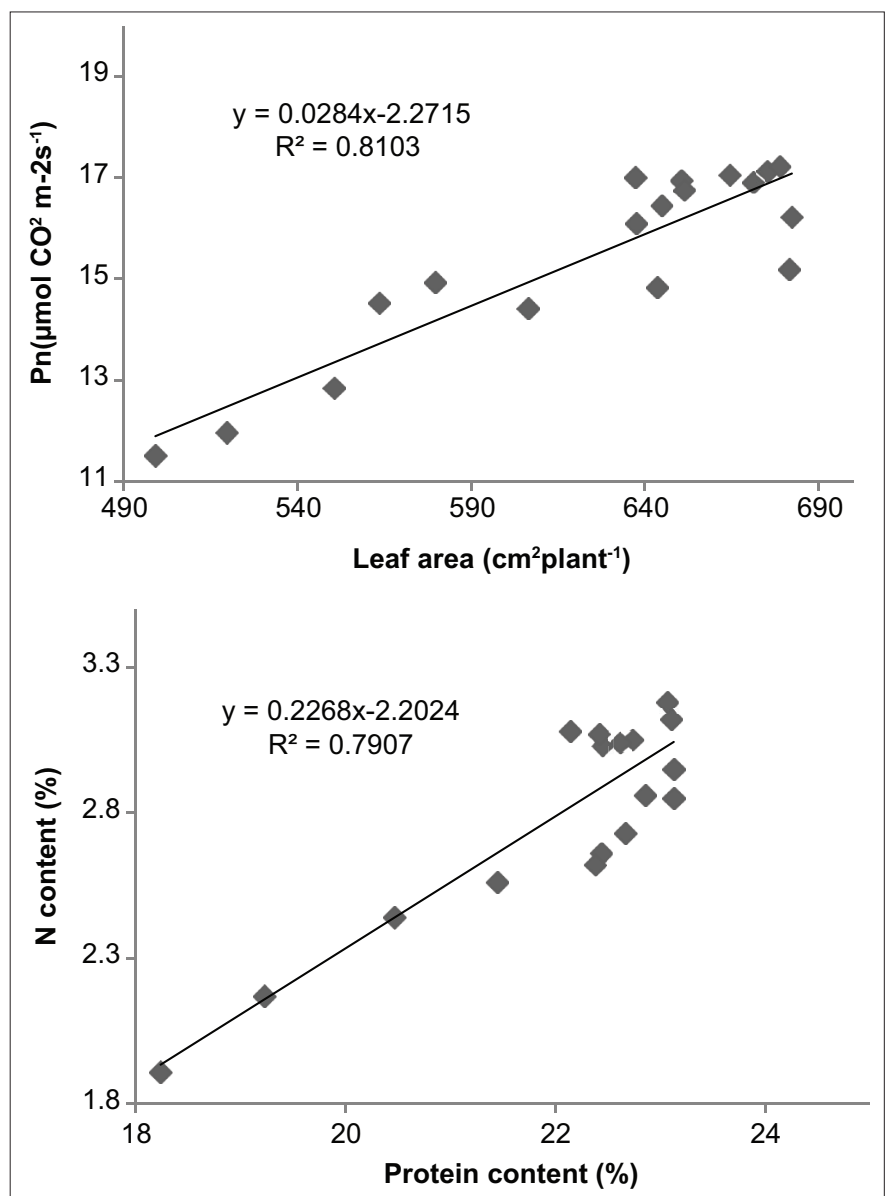

Figure 1: Relationship between net photosynthetic rate - leaf area and $N$ content - protein content of Cicer arietinum L. under waste water and ground water irrigation along with different NPK levels.

efficiency was also significantly improved in plants irrigated with wastewater. Among the treatments $\mathrm{N}_{30} \mathrm{P}_{40} \mathrm{~K}_{40}$ compared to control 
$\left(\mathrm{N}_{0} \mathrm{P}_{0} \mathrm{~K}_{0}\right)$ recorded an increase of $44.92 \%, 29.31 \%$, and $40.95 \%$ in net photosynthetic rate $\left(\mathrm{P}_{N}\right)$, stomatal conductance $\left({ }_{S}^{\mathrm{g}}\right)$, and water use efficiency (WUE), respectively [Table 7]. Among the interactions, wastewater along with $\mathrm{N}_{30} \mathrm{P}_{40} \mathrm{~K}_{40}$ proved to be optimum combination and all the photosynthetic parameters were proved better. The $\mathrm{R}^{2}$ values suggested a strong correlation between leaf area and the net photosynthetic rate and also between the protein content and $\mathrm{N}$ content [Figure 1]. This further strengthened that the leaf area and $\mathrm{N}$ content [Tables 6 and 8] which was increased by the wastewater irrigation and also along with the combination of fertilizers led to increase in the yield and also the protein content [Table 9] [40].

\subsection{Yield Characteristics}

The data related to yield and its related parameters, namely, pods per plant, 100-seed weight, seed yield, and protein content are presented in Table 9. Waste water irrigation improved these parameters by $9.28 \%, 3.17 \%, 9.62 \%$, and $1.41 \%$ over ground water, respectively. However, no significant differences were observed in seeds per pod. Among the treatments wastewater in general proved more effective and since the wastewater was rich in several micronutrients and the growth under wastewater irrigation increased plant morphological growth and improved physiological parameters which ultimately led to the increase in the yield of the crop. Among the NPK treatments

Table 6: Effect of GW and WW on plant (a) leaf area, (b) nitrate reductase (NR) activity, (c) chlorophyll content, and (d) carbonic anhydrase of chickpea (Cicer arietinum L.) grown under different combinations of NPK at 60 DAS.

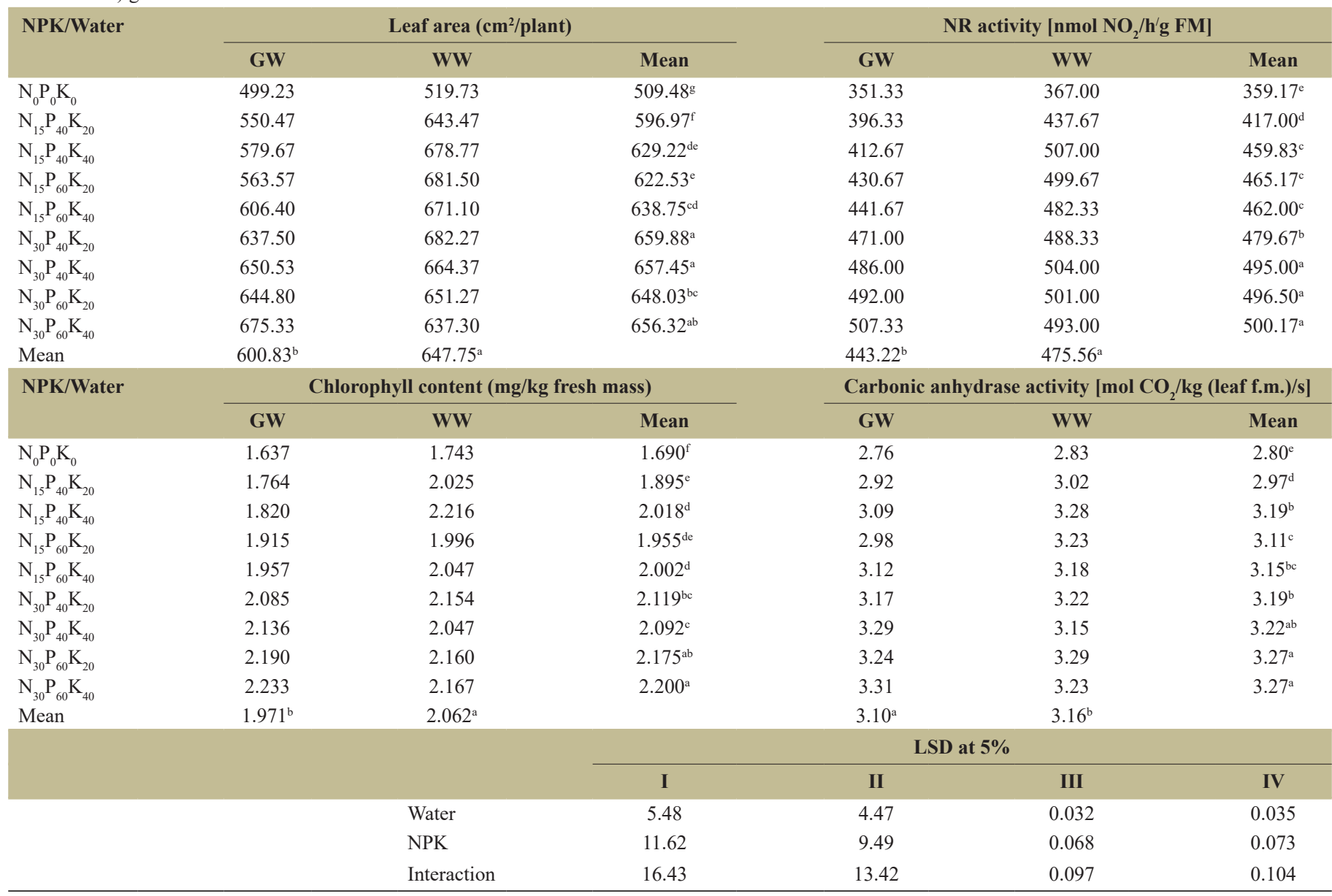

Table 7: Effect of GW and WW on plant (a) photosynthetic rate, $\left(\mathrm{P}_{\mathrm{N}}\right)(\mathrm{b})$ stomatal conductance, (c) water use efficiency, and (d) internal $\mathrm{CO}_{2}$ of chickpea $($ Cicer arietinum L.) grown under different combinations of NPK at 60 DAS.

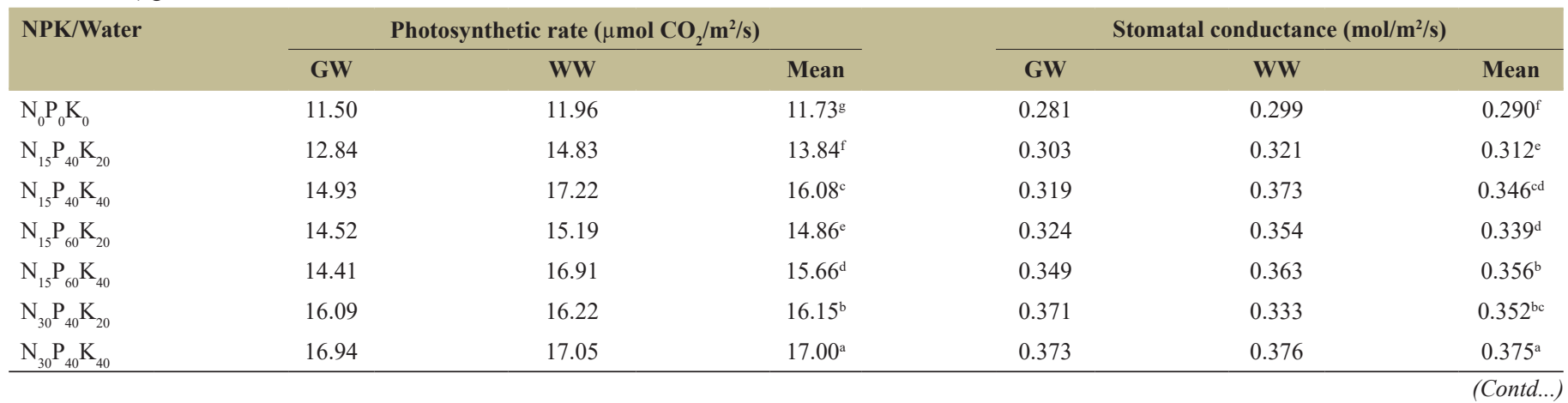


Table 7: (Continued).

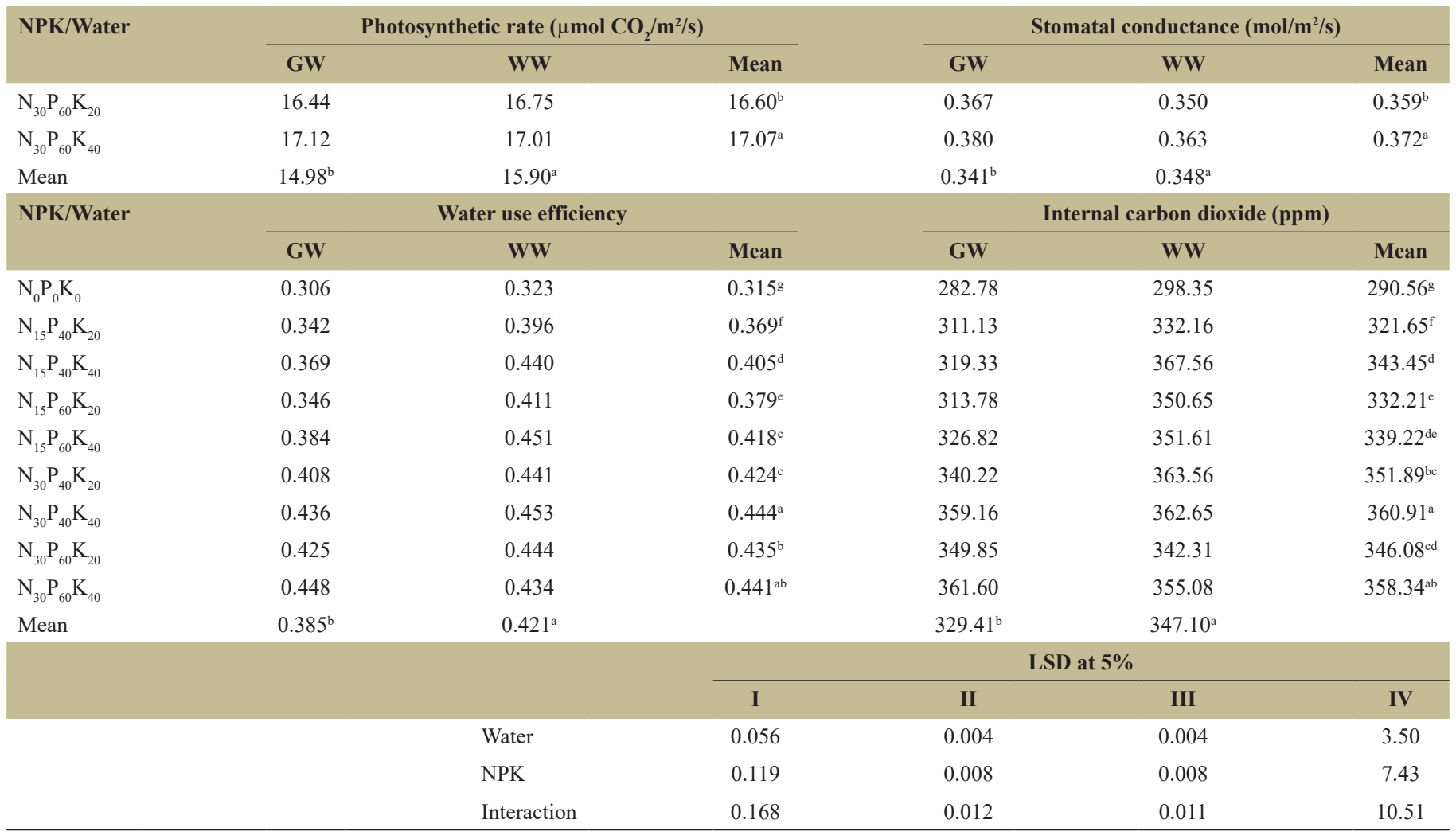

Table 8: Effect of GW and WW on plant (a) N content, (b) $P$ content, and (c) K content of chickpea (Cicer arietinum L.) grown under different combinations of NPK at 60 DAS

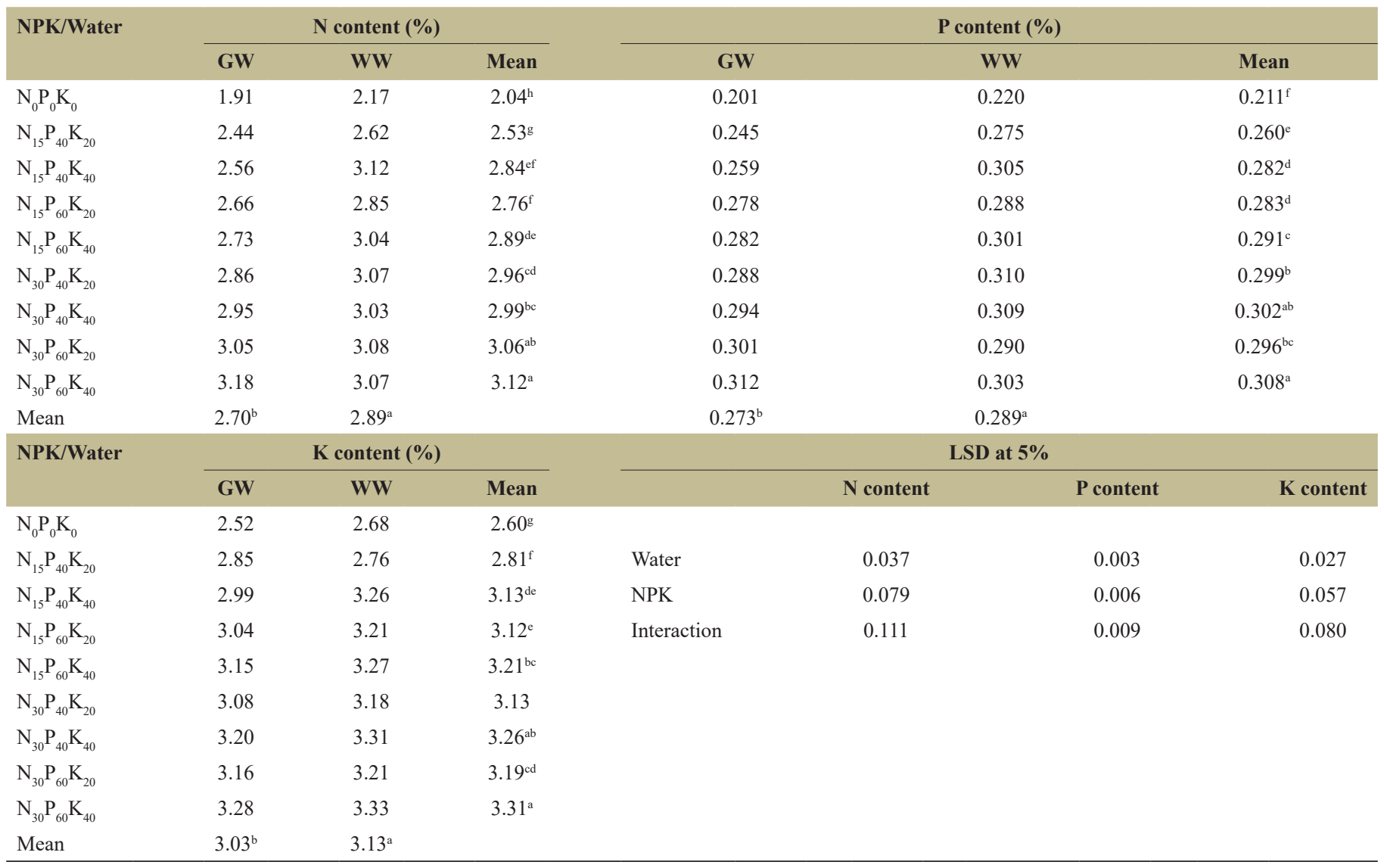


Table 9: Effect of GW and WW on yield parameters (a) seeds per pod, (b) pods per plant, (c) 100-seed weight, (d) seed yield, and (e) protein content grown under different combinations of NPK at 60 DAS.

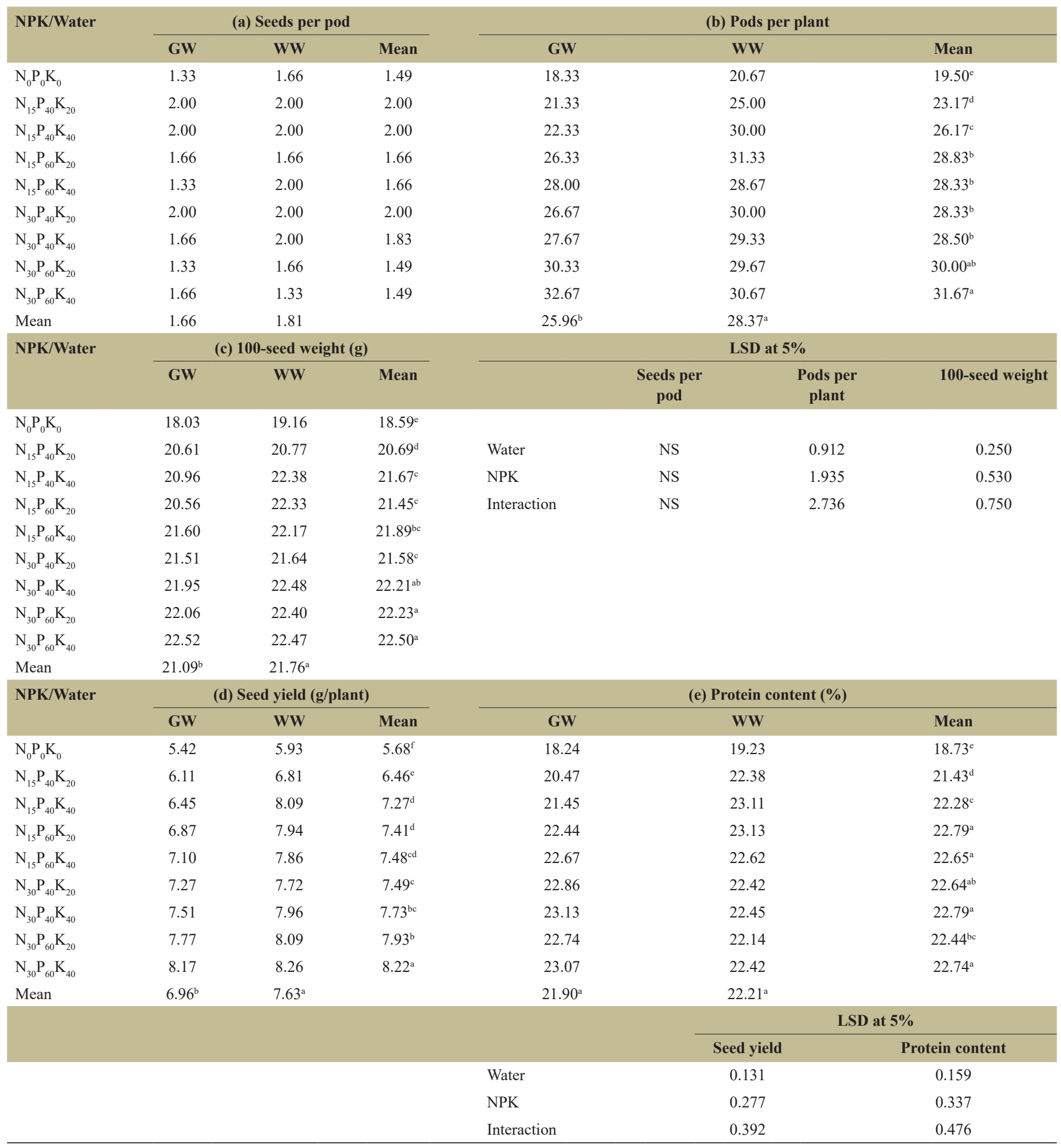

the $\mathrm{N}_{30} \mathrm{P}_{60} \mathrm{~K}_{40}$ was reported as the best combination for all the yield parameters; however, protein content the combinations $\mathrm{N}_{15} \mathrm{P}_{60} \mathrm{~K}_{20}$, $\mathrm{N}_{15} \mathrm{P}_{60} \mathrm{~K}_{40}, \mathrm{~N}_{30} \mathrm{P}_{40} \mathrm{~K}_{20}, \mathrm{~N}_{30} \mathrm{P}_{40} \mathrm{~K}_{40}, \mathrm{~N}_{30} \mathrm{P}_{60} \mathrm{~K}_{20}$, and $\mathrm{N}_{30} \mathrm{P}_{60} \mathrm{~K}_{40}$ produced at par results. The results therefore suggest that the seed yield decreased was affected significantly with different fertilizer combinations; however, the protein content was not affected in the similar pattern.

\section{CONCLUSION}

The study based upon the present set of experiments suggests that the wastewater can be not only act as a source of irrigation water but has the potential to supplement the nutritional requirement of the crops. The better growth and yield were with lower fertilizer 
combinations together with wastewater, while the higher doses proved to be luxurious. This may potentially be the result of nutritional benefits of the micronutrients present in wastewater which not only supplied the micronutrients but also the macronutrients Nitrogen and phosphorus. However, for long-term effect of this water on the changes in the physico-chemical properties of soil and any buildup of heavy metals needs to be monitored. The importance of the present study is embedded in the fact that huge amount of waste is generated in Aligarh city and this water is used for growing crops in huge agricultural lands in the outskirts. Even though this study suggests the nutritional superiority of the wastewater; however, regular monitoring is suggested for the long-term application as it may result in buildup of certain metals, particularly the Nickel which was found to be in the highest concentration among the four metals studied.

\section{ACKNOWLEDGMENTS}

The UGC research fellowship during $\mathrm{PhD}$ is also highly acknowledged and the support provided by the department is also appreciated.

\section{AUTHOR CONTRIBUTIONS}

All authors made substantial contributions to conception and design, acquisition of data, or analysis and interpretation of data; took part in drafting the article or revising it critically for important intellectual content; agreed to submit to the current journal; gave final approval of the version to be published; and agree to be accountable for all aspects of the work. All the authors are eligible to be an author as per the international committee of medical journal editors (ICMJE) requirements/guidelines.

\section{CONFLICTS OF INTEREST}

The authors report no financial or any other conflicts of interest in this work.

\section{ETHICAL APPROVALS}

Not applicable.

\section{PUBLISHER'S NOTE}

This journal remains neutral with regard to jurisdictional claims in published institutional affiliation.

\section{REFERENCES}

1. Vallino E, Ridolfi L, Laio F. Measuring economic water scarcity in agriculture: A cross-country empirical investigation. Environ Sci Policy 2020;114:73-85.

2. Hossain L, Sarker SK, Khan MS. Evaluation of present and future wastewater impacts of textile dyeing industries in Bangladesh. Environ Dev 2018;26:23-33.

3. Wallace JS. Increasing agricultural water use efficiency to meet future food production. Agric Ecosyst Environ 2000;82:105-19.

4. Tak HI, Inam A, Inam A. Effects of urban wastewater on the growth, photosynthesis and yield of chickpea under different levels of nitrogen. Urban Water J 2010;7:187-95.

5. Urbano VR, Mendonça TG, Bastos RG, Souza CF. Effects of treated wastewater irrigation on soil properties and lettuce yield. Agric Water Manag 2017;181:108-15.

6. Friedler E. Water reuse an integral part of water resources management: Israel as a case study. Water Policy 2001;3:29-39.

7. Gadallah MA. Phytotoxic effects of industrial and sewage waste waters on growth, chlorophyll content, transpiration rate and relative water content of potted sunflower plants. Water Air Soil Pollut 1996;89:33-47.

8. Lu Y, Song S, Wang R, Liu Z, Meng J, Sweetman AJ, et al. Impacts of soil and water pollution on food safety and health risks in China. Environ Int 2015;77:5-15.

9. Tak HI, Babalola OO, Huyser MH, Inam A. Urban wastewater irrigation and its effect on growth, photosynthesis and yield of chickpea under different doses of potassium. Soil Sci Plant Nutr 2013;59:156-7.

10. Lado M, Bar-Tal A, Azenkot A, Assouline S, Ravina I, Erner Y, et al. Changes in chemical properties of semiarid soils under longterm secondary treated wastewater irrigation. Soil Sci Soc Am J 2012;76:1358-69.

11. Ye Y, Ngo HH, Guo W, Chang SW, Nguyen DD, Zhang X, et al. Nutrient recovery from wastewater: From technology to economy. Bioresour Technol Rep 2020;11:100425.

12. Rusan MJ, Hinnawi S, Rousan L. Long term effect of wastewater irrigation of forage crops on soil and plant quality parameters. Desalination 2007;215:143-52.

13. Cirelli GL, Consoli S, Licciardello F, Aiello R, Giuffrida F, Leonardi C. Treated municipal wastewater reuse in vegetable production. Agric Water Manag 2012;104:163-70.

14. Qian YL, Mecham B. Long-term effects of recycled wastewater irrigation on soil chemical properties on golf course fairways. Agron J 2005;97:717-21.

15. Muyen Z, Moore GA, Wrigley RJ. Soil salinity and sodicity effects of wastewater irrigation in South East Australia. Agric Water Manag 2011;99:33-41.

16. Kaboosi K. The assessment of treated wastewater quality and the effects of mid-term irrigation on soil physical and chemical properties (case study: Bandargaz-treated wastewater). Appl Water Sci 2017;7:2385-396.

17. Pedrero F, Allende A, Gil MI, Alarcón JJ. Soil chemical properties, leaf mineral status and crop production in a lemon tree orchard irrigated with two types of wastewater. Agric Water Manag 2012;109:54-60.

18. Segal E, Dag A, Ben-Gal A, Zipori I, Erel R, Suryano S. Olive orchard irrigation with reclaimed wastewater: Agronomic and environmental considerations. Agric Ecosyst Environ 2011;140:454-61.

19. Hamilton AJ, Boland AM, Stevens D, Kelly J, Radcliffe J, Ziehrl A. Position of the Australian horticultural industry with respect to the use of reclaimed water. Agric Water Manag 2005;71:181-209.

20. Nogueira SF, Pereira BF, Gomes TM, de Paula AM, dos Santos JA, Montes CR. Treated sewage effluent: Agronomical and economical aspects on bermudagrass production. Agric Water Manag 2013;116:151-9.

21. Tak HI, Ahmad F, Babalola OO, Inam A. Growth, photosynthesis and yield of chickpea as influenced by urban wastewater and different levels of phosphorus. Int J Plant Res 2012;2012:6-13.

22. American Public Health Association. Standard Methods for the Examination of Water and Wastewater. $20^{\text {th }}$ ed. Washington, DC: American Public Health Association; 1999.

23. Jackson ML. Soil Chemical Analysis: Advanced Course. Brazil: UW-Madison Libraries Parallel Press; 2005.

24. Ghosh AB, Bajaj JC, Hasan R, Singh D. Soil and Water Testing Methods: A Laboratory Manual. New Delhi; IARI; 1983. p. 31-6.

25. Sadasivam S, Manickam A. Biochemical Methods for Agricultural Science. $2^{\text {nd }}$ ed. New Delhi: Wiley East Ltd.; 1992.

26. Jaworski EG. Nitrate reductase assay in intact plant tissues. Biochem Biophys Res Commun 1971;43:1274-9.

27. Dwivedi RS, Randhawa NS. Evaluation of a rapid test for the hidden hunger of zinc in plants. Plant Soil 1974;40:445-51.

28. Lindner RC. Rapid analytical methods for some of the more common 
inorganic constituents of plant tissues. Plant Physiol 1944;19:76-89.

29. Mackinney G. Criteria for purity of chlorophyll preprations. J Biol Chem 1940;132:91-109.

30. Lowry OH, Rosebrough NJ, FarrAL, Randall RJ. Protein measurement with the Folin phenol reagent. J Biol Chem 1951;193:265-75.

31. Freeman GH, Gomez KA, Gomez AA. Statistical procedures for agricultural research. Biometrics 1985;41:342-3.

32. Ayers RS, Wescot DW. Water Quality for Agriculture. FAO Irrigation and Drainage Paper 29, Rev. 1, Reprinted 1994. Rome, Italy: Food and Agricultural Organization; 1994.

33. da Silva Cuba Carvalho R, Bastos RG, Souza CF. Influence of the use of wastewater on nutrient absorption and production of lettuce grown in a hydroponic system. Agric Water Manag 2018;203:311-21.

34. Singh PK, Deshbhratar PB, Ramteke DS. Effects of sewage wastewater irrigation on soil properties, crop yield and environment. Agric Water Manag 2012;103:100-4.

35. Mojid MA, Wyseure GC, Biswas SK. Requirement of nitrogen, phosphorus and potassium fertilizers for wheat cultivation under irrigation by municipal wastewater. J Soil Sci Plant Nutr 2012;12:655-65.
36. Al-Fredan MA. Effect of treated municipal waste water and rhizobia strains on growth and nodulation of faba bean (Vicia faba L. cv. Hassawi). Pak J Biol Sci 2006;9:1960-4.

37. Oliveira A, Pampulha ME. Effects of long-term heavy metal contamination on soil microbial characteristics. J Biosci Bioeng 2006;102:157-61.

38. Hogetsu D, Miyachi S. Role of carbonic anhydrase in photosynthetic $\mathrm{CO}_{2}$ fixation in Chlorella1. Plant Cell Physiol 1979;20:747-56.

39. Marschner HBT-MMN of HP Second E, editor. Index. San Diego: Academic Press; 2002. p. 862-89.

40. Kumar BS, Singh RV, Gupta AK, Ravinder J. Effect of nitrogen levels and cutting management on nitrogen content, protein content and protein yield of fodder oat (Avena sativa L.). Int J Curr Microbiol Appl Sci 2017;6:2077-83.

\section{How to cite this article:}

Tak HI. Modulation of photosynthesis, nitrogen fixing ability, and yield attributes of Chickpea (Cicer arietinum L.) to interactive effect NPK fertilizers and municipal wastewater irrigation. J App Biol Biotech. 2021;9(3):127-136. DOI: $10.7324 / J A B B .2021 .9316$ 